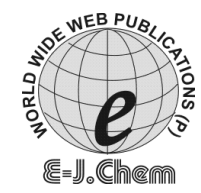

http://www.e-journals.net

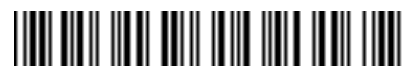

ISSN: 0973-4945; CODEN ECJHAO

E-Journal of Chemistry

Vol. 4, No. 3, pp. 307-309, July 2007

\title{
Synthesis and Characterization of D-Lyxono- $\gamma$-lactone
}

\author{
ASIEH YAHYAZADEH \\ Department of Chemistry, \\ University of Guilan, P.O. Box 1914, Rasht, Iran, \\ yahyazadehphd@yahoo.com
}

Received 1 November 2006; Accepted 9 December 2006.

\begin{abstract}
D-lyxono- $\gamma$-lactone has been prepared in two steps from galactose. The first step potassium lyxonate was obtained in $64 \%$ yield and the title compound has been isolated in next step with $75 \%$ yield. The structures of the products were characterized by IR, ${ }^{1} \mathrm{H},{ }^{13} \mathrm{C}$, mass and microanalysis study.
\end{abstract}

Keywords : Lactone, Antiviral activity, Galactose, D- Lyxonate

\section{Introduction}

Oxetanocin ${ }^{1} \mathbf{1}$, was the first example of a new family of nucleosides ${ }^{2}$ containing an oxetane ring rather than a furan ring as the sugar moiety. The antiviral activity of oxetanocin and its guanin analogue $\mathbf{2}$ has stimulated considerable interest in the synthesis of oxetanecontaining nucleosides ${ }^{3,4}$.

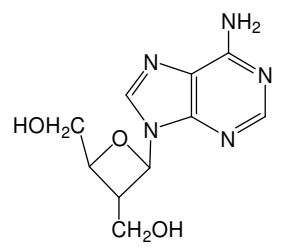

1

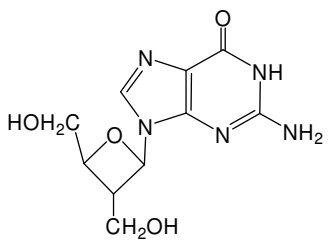

2

Most of these derivatives have been synthesized by Fleet's group $\alpha$ - and $\beta$-noroxetanocin have been made by this group ${ }^{5}$ but show no activity against HIV-1 in vitro, however a structural isomer epinoxoxetanocin ${ }^{6}$ shows considerable anti-HIV activity in vitro.

The azido $\mathbf{3}$ and fluro $\mathbf{4}$ analogues of noroxetanocin have also been synthesized ${ }^{7}$ by Fleet's group and whilst the fluoro derivative shows no significant activity against HIV-1, the azido analogue shows significant anti-HIV activity in vitro. 
<smiles>Nc1ncnc2c1ncn2C1OC2COCC21</smiles>

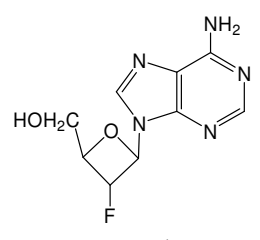

\section{Experimental}

The ${ }^{1} \mathrm{H}$ NMR spectra were recorded on Hitachi-Perkin-Elmer R24B (60 MHz) or Bruker XL $500(500 \mathrm{MHz}$ ) instruments (with J-values given in $\mathrm{Hz}),{ }^{13} \mathrm{C}$ NMR spectra (with DEPT 135) either on a Bruker WP80 or XL500 instrument, and IR spectra on a Shimadzu IR-470 spectrophotometer. Mass spectra were recorded on a Kratos Concept instrument. The melting points were measured on an Electrothermal digital melting point apparatus and are uncorrected.

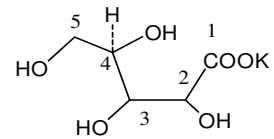

6

Preparation of potassium D-lyxonate (6)

A four necked, five litre flask equipped with a heavy duty mechanical stirrer, reflux condenser and dropping funnel was charged with a solution of potassium hydroxide $(168.0 \mathrm{~g}, 3 \mathrm{~mol})$ in water $(360 \mathrm{~mL})$ and methanol $(1500 \mathrm{~mL})$. into the warm $\left(30-45^{\circ} \mathrm{C}\right)$, vigorously stirred solution was passed oxygen gas via two syringe needles and simultaneous addition of a solution of D-galactose (180.0 g, $1 \mathrm{~mol})$ in water $(360 \mathrm{~mL})$ was made via the dropping funnel over a $4 \mathrm{~h}$ period. After the addition, the passage of oxygen through the solution was continued for a further two hours; methanol was added periodically throughout the reaction to replace that lost due to evaporation. Air was then bubbled through the stirred solution for $48 \mathrm{~h}$. After this period the solution was diluted to twice its volume with methanol and stirred at room temperature for one day. The solid was filtered and dried under vacuum to give $130.0 \mathrm{~g},(0.64 \mathrm{~mol} ; 64 \%)$ of $\mathbf{6}$. An analytical sample was prepared by recrystallisation $(1: 2$ water : methanol) to give colourless cubes, m.p. $167-170{ }^{\circ} \mathrm{C}$ (dec.) $\left[\right.$ lit. $\left.{ }^{8} 166{ }^{\circ} \mathrm{C}\right]$ Found : C, $29.1 ; \mathrm{H}$, 4.4\%. Calc. for $\left.\mathrm{C}_{5} \mathrm{H}_{9} \mathrm{O}_{6} \mathrm{~K}: \mathrm{C}, 29.4 ; \mathrm{H}, 4.4 \%\right] ;{ }^{1} \mathrm{H}$ NMR $\left(\mathrm{D}_{2} \mathrm{O}\right): \delta 3.55-3.60\left(\mathrm{~m}, 2 \mathrm{H}, \mathrm{CH}_{2} \mathrm{OH}\right), 3.75$ (dd, 1H, J 6, 3Hz, H3), 3.85 (m,1H, H4), 4.08 (d, 1H, J 6Hz, H2) ppm; ${ }^{13} \mathrm{C} \mathrm{NMR}\left(\mathrm{D}_{2} \mathrm{O}\right) ; \delta 64.1\left(\mathrm{CH}_{2}\right.$, by Dept 135), $73.0(\mathrm{CHOH}), 72.4(\mathrm{CHOH}), 74.7(\mathrm{CHOH}), 180.1$ (COOK), ppm; $v_{\max }$ (Nujol) 3700$2300 \mathrm{bs}(\mathrm{OH}), 1600 \mathrm{~s}(\mathrm{C}=\mathrm{O}), 1130 \mathrm{~s}, 1110 \mathrm{~s}, 1040 \mathrm{~s}, 990 \mathrm{~s}, 870 \mathrm{~s}$, and $830 \mathrm{~cm}^{-1}$.
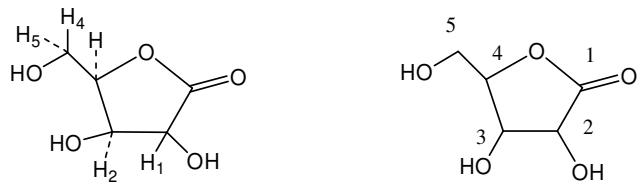

\section{Preparation of D-lyxono- $\gamma$-lactone (7)}

Into a mechanically stirred suspension of potassium-D- lyxonate $(173.0 \mathrm{~g}, 0.85 \mathrm{~mol})$ in isopropyl alcohol $(700 \mathrm{~mL})$ was passed hydrogen chloride gas for twenty mins. The mixture was then cooled in ice and passage of the gas was continued for a further 20 mins. The mixture was then heated to boiling and the precipitated potassium chloride was filtered under suction and rinsed with isopropyl alcohol. The filtrate and washing were concentrated under reduced pressure to about $150 \mathrm{~mL}$ when the product precipitated and this was collected 
by filtration $(77 \mathrm{~g})$. Further concentration of the mother liquod yielded a second crop of 7 giving a total yield of $94 \mathrm{~g}(0.65 \mathrm{~mol} ; 76 \%)$. An analytical sample was obtained by recrystallisation (isopropyl alcohol) to give small needles, m.p. $110-111{ }^{\circ} \mathrm{C}$ (lit. ${ }^{9}, 114{ }^{\circ} \mathrm{C}$ ) Found : C, 40.8; H, 5.4\%; $\left(\mathrm{M}+\mathrm{NH}_{4}\right)^{+}=166(100 \%)$. Calc. for $\mathrm{C}_{5} \mathrm{H}_{8} \mathrm{O}_{5}: \mathrm{C}, 40.5 ; \mathrm{H}, 5.4 \% ; \mathrm{M}$ 148]; ${ }^{1} \mathrm{H}$ NMR $\left(\mathrm{D}_{2} \mathrm{O}\right): \delta 3.90(\mathrm{~m}, 2 \mathrm{H}, \mathrm{H} 4 \& \mathrm{H} 5), 4.55$ (dd, $1 \mathrm{H}, \mathrm{H} 2, \mathrm{~J}_{1,2} 6 \mathrm{~Hz} ; \mathrm{J}_{2,3} 3.5 \mathrm{~Hz}$ ), $4.60\left(\mathrm{~m}, 1 \mathrm{H}, \mathrm{H}_{3}\right), 4.70\left(\mathrm{~d}, 1 \mathrm{H}, \mathrm{J}_{1,2} 6 \mathrm{~Hz}, \mathrm{H} 1\right) \mathrm{ppm} ;{ }^{13} \mathrm{C}$ NMR $\left(\mathrm{D}_{2} \mathrm{O}\right) ; \delta 60.9$ (C5, by Dept 135) 70.7 (C4), 71.7 (C3), 82.7 (C2), 179.4 (C1) ppm; v $v_{\max }$ (Nujol) 3700-3100b (OH), 1780s $(\mathrm{C}=\mathrm{O}), 1640 \mathrm{~m}, 1320 \mathrm{~m}, 1200 \mathrm{~s}, 1100 \mathrm{~s}, 1020 \mathrm{~s}, 990 \mathrm{~s}, 960 \mathrm{~s}, 870 \mathrm{~s}, 800 \mathrm{~s}$ and $780 \mathrm{~s} \mathrm{~cm}^{-1}$.

\section{Results and Discussion}

D-lyxono- $\gamma$-lactone 7 was prepared in two steps from galactose $\mathbf{5}$.

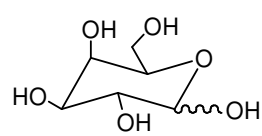

5

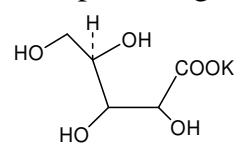

6

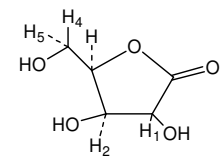

7

Oxidation of an alkaline solution of D-galacose on a molar scale, by a method based on the oxidation of glucose, afforded potassium lyxonate 6 in $64 \%$ yield. The product as expected showed 5 lines in the ${ }^{13} \mathrm{C}$ nmr, a series of multiplets in the ${ }^{1} \mathrm{H} N M R$, broad $\mathrm{OH}$ and $\mathrm{C}=\mathrm{O}$ stretching in the infrared, and the microanalysis results were satisfactory.

Cyclisation of 6 with hydrogen chloride gas in isopropanol ${ }^{8-12}$ gave D-lyxono- $\gamma$-lactone 7 in $75 \%$ yield. The product again showed 5 lines in the ${ }^{13} \mathrm{C}$ NMR, the mass spectrum $(\mathrm{CI})$ showed a $\left(\mathrm{M}+\mathrm{NH}_{4}\right)^{+}=166$ and the microanalysis results were consistent. The ${ }^{1} \mathrm{H}$ NMR shows $\mathrm{H} 1$ appearing as a doublet $(\mathrm{J} 6 \mathrm{~Hz})$ by coupling with the cis $\mathrm{H} 2$ which itself appears as a doublet of doublets $(\mathrm{J} 6,3.5 \mathrm{~Hz}$ ) by additional coupling to $\mathrm{H} 3$; both $\mathrm{H} 4$ and $\mathrm{H} 5$ appear as complex multiplets. The infrared shows broad $\mathrm{OH}$ stretching and a sharp $\mathrm{C}=\mathrm{O}$ absorption at $1780 \mathrm{~cm}^{-1}$ which is consistent with the molecule being a cyclic 5-membered lactone.

\section{Acknowledgments}

We are thankful to the Guilan University Research Concil for the partial support of this work.

\section{References}

1 Shimada N, Harada S, Tomisawa T Fujii A and Takito T, J. Antibiotics, 1986, 39, 1623.

2 Yamamoto Y, Fujioka N Shimada N and Takahashi J, J. Antibiotics, 1989, 42, 1308.

3 Norbeck D W and Kramer J B, J. Amer. Chem, Soc. 1988, 110, 7217.

$4 \quad$ Nagai M, Kato K, Nishiyama K and Yamamura S, Tetrahedron Lett. 1990, 31, 119.

5 Wlison F X, Fleet G W, Witty D R, Myers P, Storer R, Wallis C, Watkin D and Voget K, Tetrahedron Assym., 1990, 1, 525.

6 Fleet G W, Wlison F X, Storer R, Voget K, Watkin D, Witty D R and Peach J, Tetrahedron Lett. 1991, 32, 1675.

7 Bashgal B, Chow H and Fleet G W Tetrahedron, 1987, 43, 423.

8 Norbeck D and Kraner J, J. Amer. Chem. Soc., 1988, 110, 7217.

9 Humphlett W J, Carbohyd. Res., 1967, 4, 157.

10 Yahyazadeh A and Sharifi Z Phosphorus, Sulfur, and Silicon, 2006, 6, 1339.

11 Al-Azmi A, Elassar A A and Booth B L, Tetrahedron, 2003, 59, 2749.

12 Yahyazadeh A, Russ. J. Org. Chem., 2003, 39, 1718. 


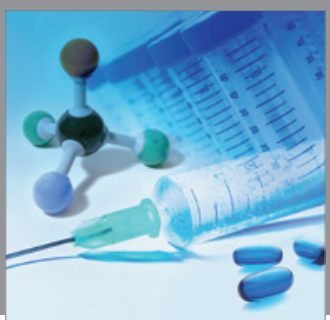

International Journal of

Medicinal Chemistry

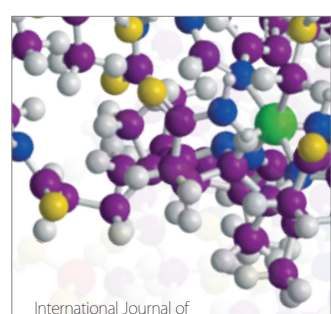

Carbohydrate Chemistry

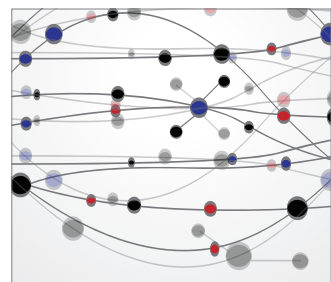

The Scientific World Journal
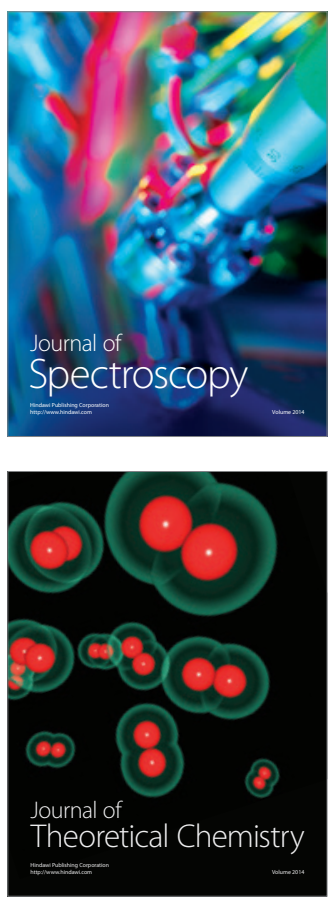
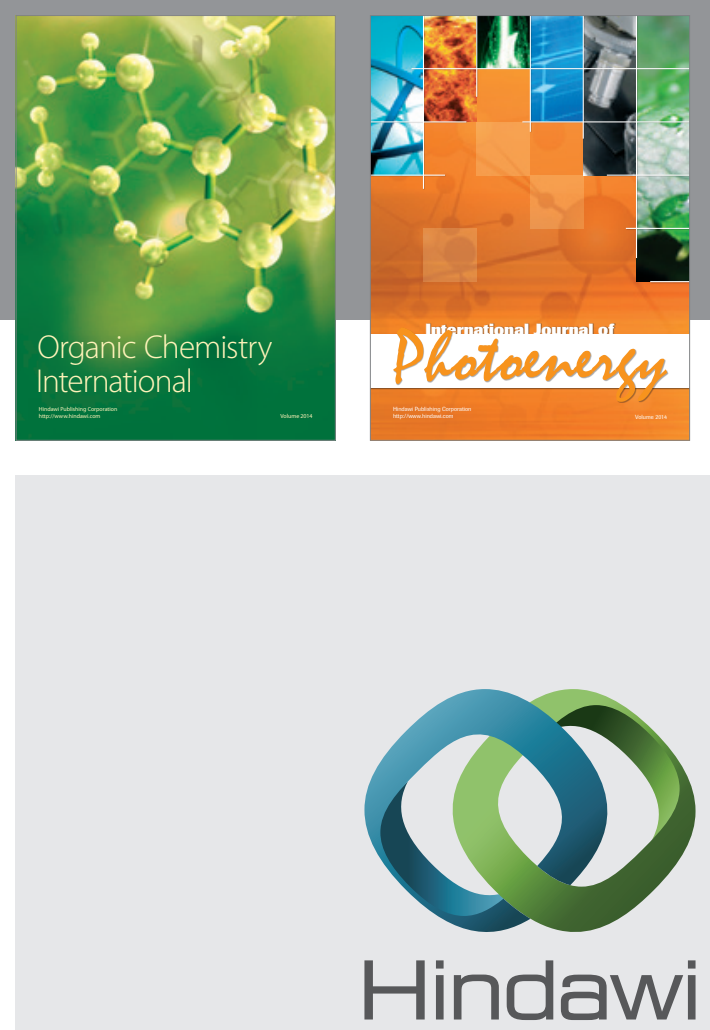

Submit your manuscripts at

http://www.hindawi.com
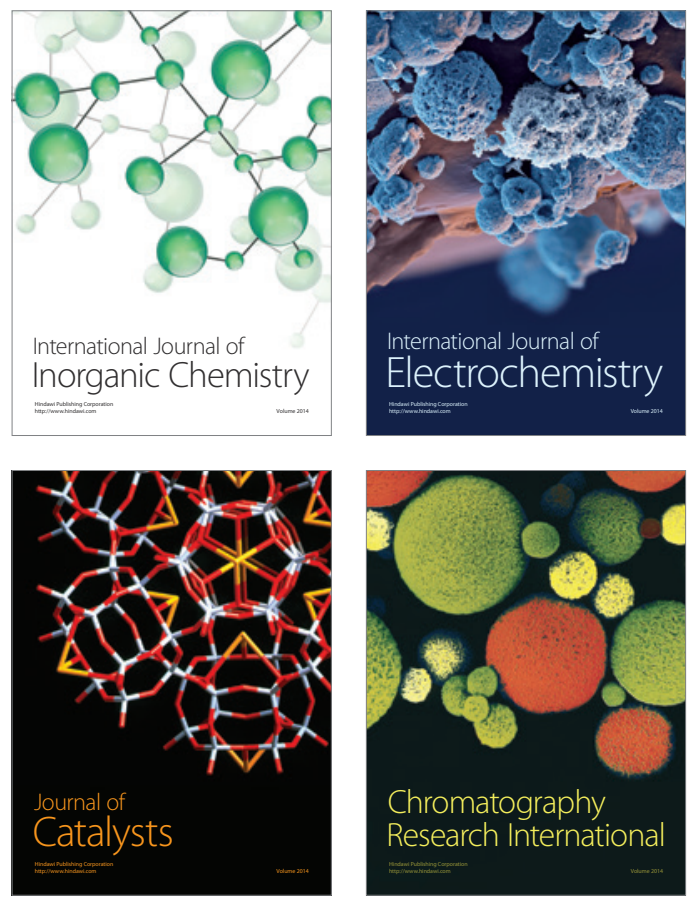
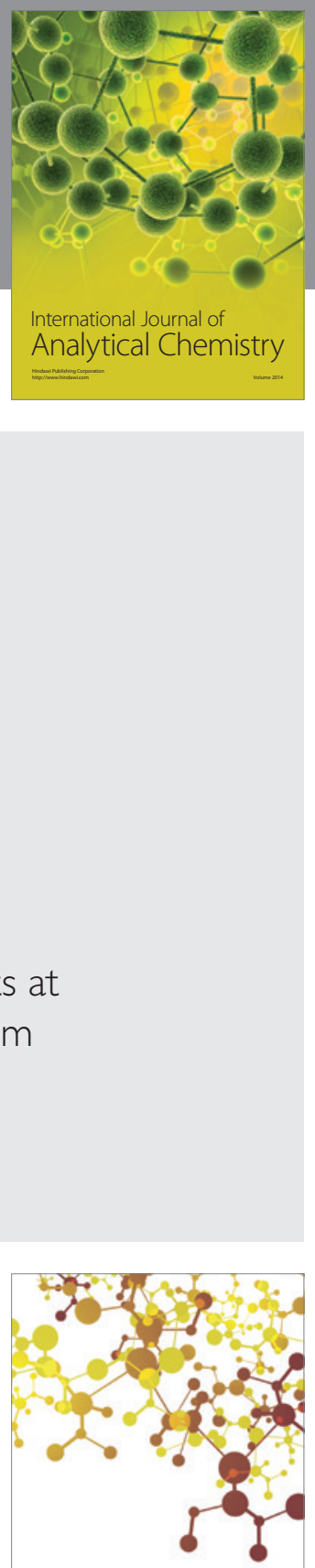

Journal of

Applied Chemistry
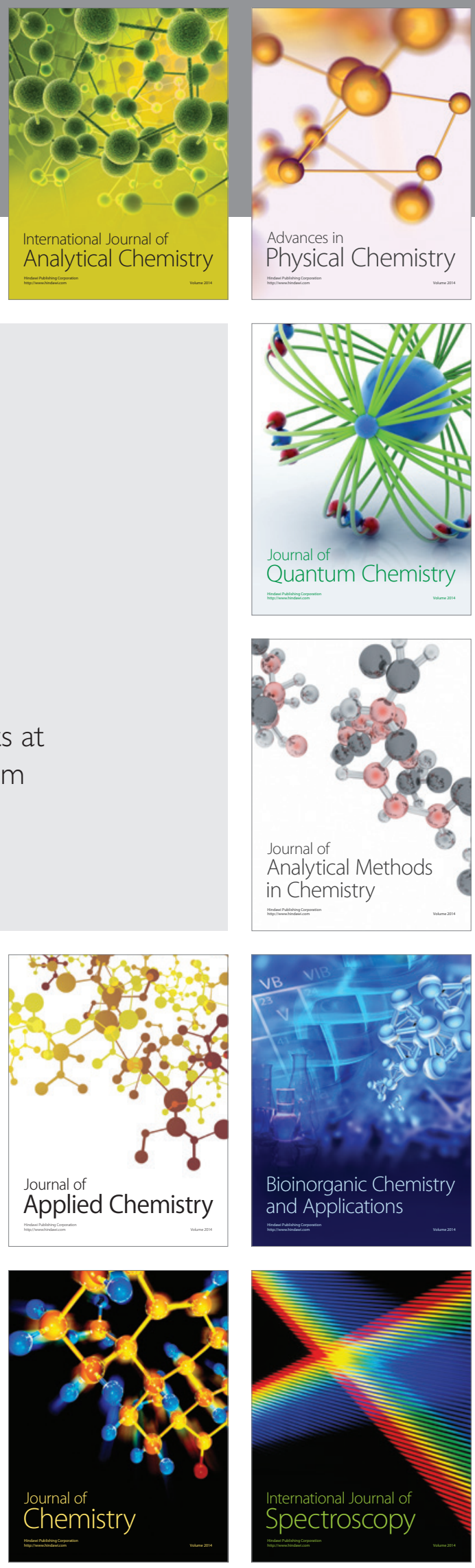